\title{
An Islamic Account of Reformed Epistemology (Draft Version)
}

\author{
Jamie B. Turner \\ Department of Philosophy: Ibn Haldun University, Turkey
}

(All citations should refer to the official manuscript - "An Islamic Account of Reformed Epistemology." Philosophy East and West, Project MUSE muse.jhu.edu/article/745033.)

Reformed Epistemology (RE) is roughly "the thesis that religious belief can be rational without arguments." To a large extent RE is centered upon a rejection of the evidentialist objection to theism. Let the evidentialistobjection be the thesis that one can only hold proposition $p$, namely that God exists, justifiably if and only if one supplies evidence $E$ in support of $p$. Assuming one does not have $E$, it follows that one would be unjustified in upholding $p$. Advocates of RE, against to this objection, hold that belief in God can be justified without recourse to propositional evidence. Alvin Plantinga, RE's prime proponent, has argued on the basis of what he coins the AquinasCalvin (or A/C) model that theistic belief can be properly basic with respect to warrant.

Plantinga's account of RE is a form of epistemic externalism. Externalism is regarded as simply the denial of internalism, which is roughly the thesis that "the justifying reason for a basic belief, or indeed for any belief, must somehow be cognitively available to the believer himself'. ${ }^{2}$ Externalists generally hold that although "there must in a sense be a reason why a basic belief is likely to be true, the person for whom such a belief is basic need not have any cognitive grasp of this reason." In other words, a belief can result from "factors external to the consciousness of the believer: factors involving how that belief is caused, or how well it tracks the facts, or how reliably it is formed" and still be warranted. ${ }^{4}$ Plantinga uses the term warrant to denote "that quantity, enough of which is what distinguishes knowledge from mere true belief'. ${ }^{5}$ He sets out to construct an account of warrant which is coined 'proper functionalism'. ${ }^{6} \mathrm{He}$ argues that a particular belief can have warrant if and only if it arises in the following way:

1. The belief is produced within a subject from cognitive faculties that are functioning properly, according to how they have been designed to operate. ${ }^{8}$

2. Those cognitive faculties are functioning in an epistemic environment for which they were designed to function properly.

3. The design plan of those cognitive faculties is such that they are aimed toward the acquisition of true belief.

4. The design plan of those cognitive faculties aims successfully at acquiring true beliefs. The design plan is a "good one" to the extent that there is a high probability that beliefs produced by such cognitive faculties will be true. 
Therefore, only a belief produced by cognitive faculties that are functioning properly, successfully aimed at truth, and in conjunction with epistemic environments that allow this to be brought about can be a belief that possesses warrant. In accordance with these conditions, Plantinga argues that 'basic beliefs' such as perceptual, memory based, or a priori beliefs can be warranted without propositional evidence. Plantinga refers to these beliefs as properly basic, and he thinks that theistic belief, like perceptual or memory based beliefs, can also be properly basic with respect to warrant. In Warranted Christian Belief, Plantinga proposes this thesis by building on the ideas of proper functionalism and basicality through the construction of a model coined the Aquinas/Calvin model. Following Aquinas and Calvin, the A/C model holds that God has placed within human beings a capacity to know Him in an immediate way, a sensus divinitatis. ${ }^{9}$ It is through this innate divine sense that human beings in a variety of circumstances can come to know of God in a basic way. Plantinga goes on to extend the A/C model specifically for Christian belief, such that if the model is true, Christian belief would be warranted in a properly basic manner.

Having considered the basic tenets of Plantingan RE, I am interested in this paper to consider the extent to which Plantinga's epistemology may be grounded and extended in a uniquely Islamic way. In order to examine this question, I will begin by evaluating the merits of an existing model offered in the literature by Erik Baldwin (and Tyler McNabb). ${ }^{10}$ Contrary to Baldwin's proposal, I hold that this account fails to offer a genuine extension of Plantingan epistemology because the account is not compatible with the $\mathrm{A} / \mathrm{C}$ model and its strong externalist ethos. Upon this demonstration, I shall then propose an alternative model from within the Islamic tradition, drawing on the theological epistemology of the Islamic theologian Ibn Taymiyya, from which an account that seems to be genuinely compatible with Plantinga's A/C model can be constructed.

\section{Baldwin's Islamic Extension Model}

In his paper (2010), Erik Baldwin attempts to construct an Islamic account of RE in concurrence with Plantinga's A/C model and the epistemic tenets of proper functionalism. He argues that just as Plantinga offers an extension of the $\mathrm{A} / \mathrm{C}$ model for Christian Belief $(\mathrm{CB})$, a similar extension can be made in the case of Islamic Belief (IB). According to the model, IB is warranted in much the same way as Plantinga proposed for CB: it upholds the central elements of Plantinga's model and is said to be compatible with his account of proper functionalism. Baldwin suggests that the tenets of the model and its compatibility with Plantingan RE can be demonstrated in relation to what he considers to be the three primary elements of the A/C model: the dependency, the design, and the immediacy theses. ${ }^{11}$ In brief, the dependency thesis holds that human beings are both ontologically and epistemologically dependent upon God. Second, the design thesis maintains that God created 
human beings and their faculties in accordance with a particular design plan that is successfully aimed at producing true beliefs. Finally, the immediacy thesis concerns the manner in which the belief is acquired. It holds that God has created human beings with certain cognitive faculties so that they are able to have knowledge of Him in an immediate and basic way.

The contention in this paper is that Baldwin's model is, in fact, incompatible with Plantingan $\mathrm{RE}$ in relation to two of the three aforementioned elements: the design and immediacy theses. Given that I do not hold there to be any incompatibility between Baldwin's model and Plantinga's 'dependency thesis', I need not spend much time evaluating this as such. Suffice it to say that Baldwin, through reference to the Qur'an, provides sufficient grounds from which one can grant that the model adopts this element of 'dependency'. ${ }^{12}$ The thesis, in tandem with the Qur'an, holds clearly that human beings and their cognitive faculties are dependent upon God in both the epistemic and the ontological sense. ${ }^{13}$ Thus, I will spend the remainder of this section examining the two other conditions. If Baldwin's model can be deemed compatible in these two elements, it would follow that his Islamic account of RE is sufficiently Plantingan.

\section{A Critique of Baldwin's Design Thesis}

According to Baldwin, the Plantingan 'design thesis' holds that human beings have been created with different cognitive faculties in accordance with a design plan aimed at producing true beliefs. Baldwin identifies these cognitive faculties as sensory perception, reason ('aql) and the heart (qalb) ${ }^{14}$ Sensory perception enables one to have knowledge of things in the external world. The faculty of the heart enables one to access knowledge of the spiritual domain, and through its intuition one can obtain a direct awareness of God. Reason ('aql) is divided into two sub-faculties: (a) 'aql1, responsible for formal reasoning, insight, and cognition, and (b) 'aql2, responsible for self-conscious reflection and meta-level thinking. Baldwin adds a further element within the epistemic scheme along with these faculties, namely, the "capacity for doubt". ${ }^{15}$ The idea is that the 'design plan' God has in store for His creatures is one such that doubts will be a natural part of the process. Through the heart, one is able to experience a first-order awareness of God, i.e., basic belief in Him. But given that, according to the 'design plan', one will naturally come to doubt these basic beliefs in the divine, "aql2 functions in order to check the "veracity" of these first-order experiences in order for the believer to be certain about his belief in God and reach a higher epistemic state beyond the first-order level. Crucially, the model holds that in order for one's basic belief in God to have warrant, it must involve a combination of both the heart and ' $a q 12 .{ }^{16}$

In order to examine this thesis, it is imperative to consider more closely what is intended by the function of 'aql2. Baldwin refers to 'aql2 as meta-cognition or second-order awareness and, more precisely, as a "limited-awareness" condition. It is said to refer to the conscious awareness 
of one's first order beliefs, such that upon its active function one is able to "self-consciously consider and judge correctly [that] what initially seems true (at the object level) is known as true (at the meta level)." "17 Through this conscious reflection, one is able to deal with any doubts about the veracity of the spiritual deliverances of the heart and secure one's basic belief with warrant. Now, the notion of second-order awareness does perhaps have an Islamic basis. Deborah Black, writing on Ibn Sina (Avicenna) and the concept of certainty, explains that:

Certitude for Avicenna does contain an important subjective component, that is, confidence that one holds a true belief, or knowledge that one knows. Without that subjective component we will not have certain knowledge even if our belief is both true and justified. ${ }^{18}$

Perhaps Baldwin conceives of this second-order awareness requirement in much a similar way. However, this understanding of meta-level cognition seems very limited in its epistemic function. If it simply relates to a subjective confidence in one's beliefs based on inner reflection, it is unclear how it actually addresses doubts in any 'objective' sense without the function of 'aql1, and a reliance on 'aql in full would seem to be suggestive of an internalistepistemic position. If internalism (as mentioned above) is roughly the thesis that "the justifying reason for a basic belief, or indeed for any belief, must somehow be cognitively available to the believer himself," 19 it seems that for a second-order awareness condition to have some form of distinct epistemic function, one which furnishes one's belief with warrant, this condition would have to imply something close to that thesis of internalism. This is because one would surely need to be aware of the reasons that grant a belief warrant in order for it to be meaningfully different from a "trivial" iteration of what one already knows at the first-order level. Hence, 'aql1 would be necessary as well as 'aql2. But in that case, the model begins to drift away from its initial externalist ethos and ventures toward a type of moderate internalism perhaps. However, according to Baldwin, the second-order awareness condition cannot be understood in these terms. Rather, what is meant by it is a "qualitatively rich awareness of the reality" of one's beliefs. Baldwin articulates it in the following way:

The difference between first-order, object-level knowledge and non-trivial, secondorder knowledge is analogous to the difference between (a) knowing non-reflectively ... the fact that a distant object in your visual field is probably a Fuji apple and (b) knowing that an object at hand is a Fuji apple because you are an expert Fuji apple inspector who is focusing intently on the fact that you are eating one for lunch. ${ }^{20}$

The problem here is that it is hard to imagine how this analogy genuinely highlights the distinction between knowledge at the first - and second-order levels. In case (b), what is supposedly 
meant to represent second-order awareness obviously involves certain prior knowledge that is irrelevant to a purely second-order experience. It does not explain anything significant about bow second-order awareness in itself reaches a qualitatively richer epistemic state (without entering into the realms of internalism or otherwise being trivial). Perhaps one can frame this another way; consider the following suggestion provided by Baldwin and McNabb:

According to Ibn Sina, by reflecting on the nature of our own existence, together with reflection on the nature of existent things, we are able to come to know that all created things are contingent, from which we may infer that all things are metaphysically dependent on a neces sarily existing God. ${ }^{21}$

Yet, in this example too, it is hard to imagine how this process of reasoning can be confined to mere reflection at a second-order level. Reflecting at the second-order level may grant one an awareness of one's own contingency, but it takes another type of logical leap or inference to reach the position of positing a necessary being to ground all existence. Reflection of this sort would not all of a sudden make it the case that no formal reasoning or logical inference is involved. That is to say, it is inconceivable that such an argument can be reached solely on the basis of ' aql2. Rather, it must involve 'aql1 also. Yet, if that is so, then it follows that the use of reason in full is a requirement for any belief at the first-order level to be warranted. This position then becomes akin to upholding not simply a moderate internalism as suggested above, but some form of epistemic evidentialism: the position that, "for any theistic belief someone justifiedly holds, she holds that belief on the basis of adequately supporting evidence she has." ${ }^{22}$ Moreover, as Chisholm puts it, "the internalist assumes that, merely by reflecting upon his own conscious state, he can formulate a set of epistemic principles that will enable him to find out, with respect to any possible belief he has, whether he is justified in having that belief' ${ }^{23}$ Baldwin's thesis appears strikingly similar: a subject, upon active conscious reflection at the second-order level, can formulate reasons to accept the beliefs acquired at the first-order level, and it is only through this process that such beliefs can be sufficiently warranted. In contrast, Plantinga's externalism "lifts this accessibility constraint" and, contrary to Baldwin's account, holds that a belief can be sufficient for knowledge without any requirements based upon internal relations between a belief and reasons for the belief within the subject. ${ }^{24}$

One may rightly point out, however, that internalism strictly speaking is taken to be what Brown describes as the idea that "a thinker's epistemic status depends wholly on matters which are 'internal' to that thinker, rather than at least partially on matters which are 'external' to her". ${ }^{25}$ Therefore, given that Baldwin's account does include 'external' conditions, i.e., the other conditions of proper functionalism, it is not whollyinternalist. However, because the model appears 
to maintain some sort of epistemic evidentialism in respect to warrant, the position is at best a sort of halfway point between internalism and externalism. But given that Plantinga's model is forthrightly externalist in the strongest possible sense, this is not sufficient for compatibility. In fact, Bergmann asserts that "an essential feature of internalism is that it makes a subject's actual or potential awareness of some justification-contributor a necessary condition." ${ }^{26} \mathrm{He}$ suggests, contrary to Feldman and Conee, that the feature of an "awareness requirement" is something essential to internalism, ${ }^{27}$ and that, "the central point of contention between internalists and externalists is whether there is such an awareness requirement on justification., ${ }^{28} \mathrm{He}$ goes on to add that the awareness requirement he is referring to can be highlighted by reference to warrant where, "according to that requirement, a belief counts as knowledge only if the person holding the belief is aware (or at least potentially aware) of something contributing to its warrant." ${ }^{29}$ If Bergmann is right, then Baldwin's externalism is questionable.

In his paper, however, Baldwin does offer a retort to this suggestion when he considers, at least in brief, Bergmann's charge that having the added feature of an awareness requirement is inconsistent with externalism. He argues that "this inconsistency is only apparent." ${ }^{30}$ This is because according to the design plan upheld in the model, God created human beings such that they can come to believe in Him in a basic way, but, at the same time, intended that humans would be able to mature in understanding such that they could become aware of the reasons that confirm the truth of their first-order beliefs about God. He states that "on the hypothesis that God's design plan for us does include this capacity, it is necessary to acknowledge some sort of awareness condition on knowledge of God". ${ }^{31}$ However, there seems to be a few problems with this. Firstly, according to the design plan stated in this way, it appears that it is only necessary to acknowledge the potential capacity for a believer to reach an epistemic state such that he can know the reasons or evidence for the truth of his first-order beliefs about God. But it does not follow that therefore this has to be a necessary condition for warrant more generally.

Now, one may not necessarily agree with Bergmann's perspective on internalism in its entirety, but that is beside the point. Rather, the point is that given the fact that Baldwin's model follows what Bergmann holds to be essential to internalism in virtue of adding an awareness requirement to its account of warrant, it is obvious at least in part that unlike Plantinga's account, it struggles to capture a strong externalist ethos. In fact, Baldwin and $\mathrm{McNabb}$ both seem to admit this point when they state about their Islamic extension model that "due to endorsing a meta-level requirement on knowledge, it arguably ultimately fails to fully capture the spirit of Plantinga's reformed epistemology." 32 
However, the design thesis offered by Baldwin also seems to face problems in terms of its compatibility with proper functionalism. According to Plantinga, a belief is properly basic for $S$ "if and only if $S$ accepts $p$ in the basic way, and furthermore $p$ has warrant for $S$, accepted in that way". ${ }^{33}$ According to Plantinga's theory of warrant, as long as the conditions of proper functionalism are met in the case of a certain belief, namely that it is produced by cognitive faculties that are functioning properly, successfully aimed at truth, and in conjunction with epistemic environments that allow this to be brought about, and providing that $S$ accepts his belief $p$ in the basic way, then it follows that $p$ is warranted for $S$ at the first-order level, without any additional requirement. Therefore, if one is to add a second-order awareness requirement in the case of theistic belief or any other, then $S$ 's belief in $p$ would not be warranted until self-conscious careful reflection at the second-order level of cognition occurs. Only after its 'evaluation' can $S$ then properly accept $p$ into his scheme of beliefs. However, this notion of warrantwith respect to belief is clearly not in line with Plantingan thought. Plantinga's A/C model holds that beliefs can be warranted in the properly basic sense at the first-order level of apprehension.

\section{A Critique of Baldwin's Immediacy Thesis}

To restate it, the immediacy thesis is the idea that through the cognitive faculties with which God has endowed human beings, "God can be known in an epistemically immediate and basic manner." ${ }^{34}$ Baldwin outlines the essence of the immediacy thesis according to his model in the following way:

Although one's first-order beliefs about God ought to be confirmed by 'aql at the second-order level, qalb (spiritual perception) continues to operate as designed ... Islamic belief continues to be formed immediately in a properly basic manner at the first-order level. While there is a kind of counter-factual dependence relation at work here ... so long as one immediately perceives that one’s beliefs about God are true, one’s beliefs about God are warranted in a basic way at the first-order level despite the fact that evidence and/or reasons are required at the second-order level for this to occur. ${ }^{35}$

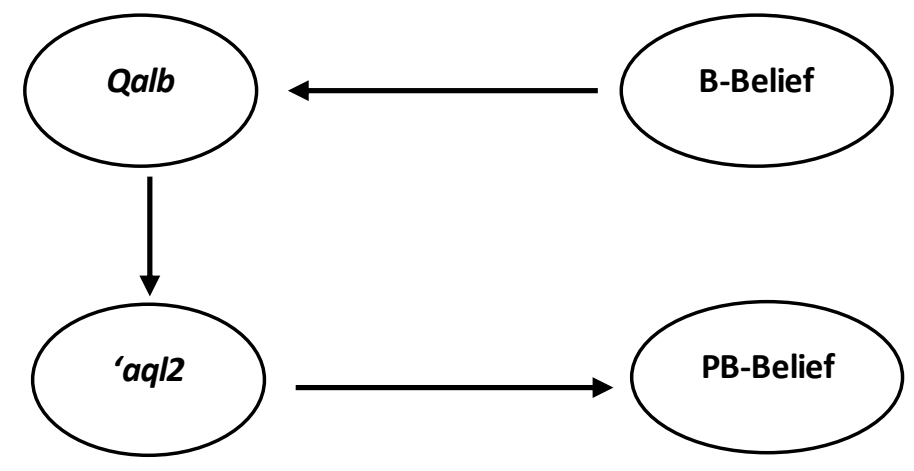


The above diagram is a simple account of what, according to the model, seems to be the way in which a properly basic belief about God is generated. The process is something like the following: B-belief (basic belief) comes to the qalb (heart) in an immediate way and is apprehended by it at the first-order level; this belief is immediate, that is, basic, but not properly basicin the sense of being warranted. Then the deliverances of the heart are further reinforced by careful, self-conscious and reflective second-order thinking performed by 'aql2, which then produces PB-Belief (properly basic belief). Baldwin suggests in the above passage that whilst 'aql2 functions to reinforce the truth pertaining to the initial belief in the qalb, the belief still remains apprehended within the qalb in a properly basic way at the first-order level, such that if one immediately comes to see that one's belief is true at the second-order level, one's basic belief is sufficient for knowledge. However, there seems to be a problem here. Baldwin holds, as quoted above, that in this process, "Islamic belief continues to be formed immediately in a properly basic manner at the first-order level". However, this is incorrect according to the model itself; the belief may be 'basic' but is not, at this stage, properly basic. This is because a belief, on this model, is only said to be sufficient for proper basicality - that is warrant - when it has fulfilled the second-order awareness requirement. So although Islamic belief can continue to be formed in an immediate and basic manner, it will not yet be, at this stage in the process a properly basic belief with respect to warrant. In contrast, the immediacy thesis of Plantinga's A/C model holds that it is. As Sudduth explains, Plantinga's immediacy thesis in conjunction with proper functionalism is roughly the following:

There are appropriate circumstances $\mathrm{C}$, such that, given any person $\mathrm{S}$, if $\mathrm{S}$ is in $\mathrm{C}$ and S's relevant cognitive faculties are functioning properly, then (i) $\mathrm{S}$ will firmly hold some corresponding theistic belief $\mathrm{T}$ in an immediate way and (ii) S's belief in $\mathrm{T}$ will be warranted to a degree sufficient [for knowledge]. ${ }^{36}$

Although Baldwin's model upholds (i) as far as it relates to the immediacy of one's belief in God at the first-order level, it does not uphold (ii) in the same way that Plantinga does. This is because it rejects the idea that (i) can be sufficient for warrant by itself. Therefore, Baldwin's model is not wholly compatible with the immediacy thesis of Plantinga's A/C model.

Thus, upon examining the central elements of Baldwin's unique Islamic extension model, I have found that it is not wholly compatible with two of the fundamental theses of Plantinga's A/C model. Consequently, an alternative account seems necessary. I intend to construct a model much closer to externalism in the Plantingan sense with reference to the ideas of the $14^{\text {th }}$-century Islamic theologian Ibn Taymiyya (d. 1328). My reliance on the work of Ibn Taymiyya is deliberate, and I have taken inspiration from the fact that some of his ideas are strikingly similar to the thesis of RE. Özervarli notes, for example, that “today, especially, reformed epistemologists strongly defend 
a view that believing in God is properly basic in human beings and does not require proving. Similarities between these views and Ibn Taymiyya's approach are quite remarkable and deserve further studies and comparative analyses. ${ }^{37}$ However, I must note that the model I am proposing in this paper, despite taking its primary inspiration from Ibn Taymiyya's epistemology of religious belief, does not claim to reduce his entire epistemological position to one of 'RE' per se, ${ }^{38}$ nor necessarily to the model I have constructed. Hence, the model is Taymiyyan in spirit, but remains my own interpretation and construction.

\section{An Alternative Islamic Account}

Let us begin by considering a formal outline of a 'Taymiyyan' model of RE:

(1) God as the Creator of the universe has instilled within human beings different cognitive faculties in order that they may acquire true beliefs about Him.

(2) God created all of mankind upon an innate natural constitution ( fit ra). This fit ra urges them to recognise Him, to know Him and to worship Him alone.

(3) The fitra has been set to work in tandem with other cognitive faculties for the production of beliefs; such faculties include, particularly in the context of theistic belief, the heart (qalb). When one's fitra functions properly, it 'triggers' within the heart an immediate awareness of God. This awareness arises within the intuition of the heart by the natural workings of the fitra upon it.

(4) The proper function of these faculties, which produces basic awareness of God, typically arises from one's direct experience of the many 'signs' (äyät) that God has placed within the world, which allows one to experience knowledge of Him in a basic manner. This knowledge of God comes to one in the basic sense in that it is immediate and involuntary.

(5) Therefore, through the epistemic role of the fitra in connection with the heart, upon the apprehension of God's distinct 'signs', belief in Him is reached immediately without the need for inference or propositional evidence.

Islamic scripture makes the theological position of premise (1) explicit in numerous places, whereby one finds that God, as the Creator of human beings, is said to have granted them different faculties for the attainment of knowledge and worship. For example, we read in the Qur'an:

It is God who brought you out of your mothers' wombs knowing nothing, and gave you hearing, sight and hearts [i.e., thinking minds], ${ }^{39}$ that you might be thankful. ${ }^{40}$

Human beings are said to have entered into the world knowing nothing, but through the God given faculties of reason and perception, they are able to acquire knowledge such that they can 
know Him and henceforth worship Him. The Qur'an also makes it clear that human beings are ontologically dependent upon God, as He is the Source and Originator of their very being: "Was there not a period of time when man was nothing to speak of? We created him from a drop of mingled fluid to put him to test; We gave him hearing and sight; We guided him to the right path, whether he was grateful or not". ${ }^{41}$ The more crucial point of relevance in this premise is the notion that God endowed human beings with different faculties for the acquisition of knowledge, i.e., reason, perceptual faculties, and the heart. This is important when considering the manner in which knowledge of God can be apprehended in a basic way. Premise (1) is self-evident, then, in terms of God's ontological status and His responsibility for the affairs of human beings.

The Islamic theologian Ibn Taymiyya is, as mentioned, the central inspiration for the model in question here. Central to Ibn Taymiyya's theological epistemology is the concept of fitra, which became in many ways its focal point. Ovamir Anjum, for example, refers to Ibn Taymiyya's emphasis on this concept of fitra as being a sort of "alternative epistemological foundation". ${ }^{42}$ The concept of fitra is introduced in the second premise of this model, which holds that God created human beings upon a natural constitution (fitra) that provides them with an innate inclination to know Him. This notion of fitra is fundamental to all of the remaining premises, and thus, it is essential that we further decipher the meaning of this concept. The concept of fitra is not one introduced by Ibn Taymiyya; rather, it is found first in the primary sources of Islam, namely the Qur'an and the prophetic traditions (hadith). Yasien Mohamed writes that at the purely lexical level, the term fitra "comes from the Arabic radicals: fa ța ra, the verbal noun being fațun ... [which] literally means: the causing of a thing to exist for the first time and the natural constitution with which a child is created in his mother's womb". ${ }^{43}$ Fitra then refers to 'something' that has been created within all mankind from the very beginning. This is evident from the Qur'an itself, where we read:

So [O Prophet] as a man of pure faith, stand firm and true in your devotion to the religion. This is the natural disposition [fitrat Alläb] that God instilled in mankind - there is no altering God's creation - and this is the right religion, though most people do not realize it. ${ }^{44}$

The above verse of the Qur'an highlights at least two key notions embedded within fitra. The first is that it refers to a sort of natural constitution upon which God created all human beings. The second is that the fitra is something innate, giving one the impression that this nature is something known to us all deep within. The prophetic traditions also contain reference to this concept and allow us to further understand the meaning of fit ra: 
Narrated [by] Abu Hurayra: God's Messenger said, 'No child is born except upon a natural constitution (fitra), and then his parents turn him into a Jew or a Christian or a Magian. ${ }^{45}$

This tradition reiterates that each human being is born upon a natural constitution. If the surrounding environment does not corrupt this disposition, the human being will acquire certain beliefs intuitively. It is only as a result of one's external environment that one can be taken away from this naturally inclined path. In explaining the meaning of fitra in the aforementioned hadith, Ibn Taymiyya states the following:

What he [the Prophet] meant is that there is a certain nature with which God created man, and that is the nature of Islam. God endowed all human beings with this essential nature the day He addressed them saying, 'Am I not your Lord?', and they said, 'Yes, we have testified', [Qur'an 7:172]. Fit ra is the original nature of man, uncorrupted by later beliefs and practices, ready to accept the true notions of Islam. ${ }^{46}$

The fitra, then, is a state that innately recognizes God, and knows Him deeply. Thus, when human beings were brought into the world, they came into it with a natural capacity through which they can come to know God. Thus, in normal circumstances they would naturally subscribe to the beliefs of Islam, which Ibn Taymiyya describes as simply the notion that "there is none worthy of worship except the One God". ${ }^{47}$ Therefore, in coming back to premise (2), namely that God created mankind upon the fitra urging them to recognise Him, and in combination with premise (1), namely that God instilled within human beings cognitive faculties in order that they may know Him, one finds that God has created human beings upon a common nature that predisposes them toward knowledge and recognition of Him.

The fitra can be said to have an intimate connection with other faculties of knowledge. Jon Hoover writes that according to Ibn Taymiyya, the fittra is "an innate faculty", and by it one instinctively comes to know God in much the same way as "an infant's instinct for his mother's milk [operates]. If nothing impedes the infant, such as illness in himself or his mother, he will necessarily drink. The shaykh [Ibn Taymiyya] adds that the natural constitution [fitra] to believe in God is even stronger than the infant's instinct." 48 What Hoover suggests, then, is that Ibn Taymiyya understands the fit ra to be a sort of faculty by which one naturally comes to know God, perhaps a sort of sensus divinitatis. Sophia Vasalou, in her work Ibn Taymiyya's Theological Ethics, writes that "human beings, Ibn Taymiyya thus claims, are born with a knowledge [of]—or, more accurately, with a disposition to know-God". She quotes Ibn Taymiyya as stating that, "one's nature itself requires that one acknowledge one's Creator ... love Him and sincerely devote oneself to His service". ${ }^{49}$ Ibn Taymiyya, in elucidating these ideas, explains that the fitra indeed refers to 
an innate capacity, but also an urge to know God and moral goodness. He states: "It has been shown that in the human being's natural disposition [i.e., fit ra], there exists a power [or urge] to believe in truth and to intend the beneficial ... The fit ra has a power [or urge] to know and believe in the Creator ... The fitra [also] has a power [or urge] for His Oneness", ${ }^{50}$

In his epistemological framework, Ibn Taymiyya acknowledges a number of knowledgebearing faculties, such as the faculties of perception, reason and the heart. ${ }^{51}$ In the case of fitra however, it is not construed as being an independent faculty in the same sense. Ibn Taymiyya suggests that the residing place of fitra is the heart. He writes: "[God] made the original nature [i.e., fitra] of His servants ready to understand the truth of things and to know them. And if it were not for this readiness within the hearts to know the truth, neither speculative reasoning would be possible, nor demonstration, discourse or language". ${ }^{52}$ He continues by adding that, "just as God made the physical bodies ready to be nourished with food and water, and had it not been for that, it would not have been possible to nourish and nurture them [i.e., the bodies], and just as the physical bodies have the faculty to distinguish between suitable nourishment and its opposite, so is there in the heart a faculty to distinguish truth and falsehood that is greater than that". ${ }^{33}$ That faculty residing in the heart is the fitra. The question is, in what sense are the heart and fitra cognitively related? And how can this help us discern the manner in which Islamic/theistic belief can be arrived at in a properly basic way? Consider the following:

\section{Heart $(q a l b) \longrightarrow$ Fițra $\longrightarrow$ Theistic Basic Belief}

The diagram above indicates the cognitive relationship between the heart and fitra for the production of theistic belief in a basic way. First, consider the heart in terms of its epistemic function. Ibn Taymiyya writes: "If it [the heart] were left in the condition in which it was created, void of any remembrance and free of any thought, then it would accept knowledge free of ignorance and see the clear truth about which there is no doubt; consequently it would believe in its Lord and turn to Him in repentance." ${ }^{54}$ Similarly he writes that, "the heart in itself is not receptive except to the Truth [i.e., God]. When [nothing] is placed in it, it receives only that for which it was created". ${ }^{55}$ The implication is that one can come to know of God simply by the proper function of one's heart. How then is this linked to the fitra? Ibn Taymiyya asserts that "when the fitra is left unspoiled, the heart knows God, loves Him and worships Him alone". ${ }^{56}$ The fit ra, when functioning properly, then, is said to enable the heart to function to come to know of God in a basicway. That is, if left unspoiled, the fit ra will naturally facilitate a belief in God intuited by the heart. Therefore, through the natural workings of the fitra upon the faculty of the heart, man is able to know God in a basic way. As Ibn Taymiyya puts it, "The affirmation of a Creator and His 
perfection is innate and necessary with respect to one whose fitra remains intact ${ }^{\prime} .{ }^{77}$ And elsewhere he states that, "the acknowledgement of God's existence, and knowledge of Him, and loving Him, and unifying Him, are from the fitra, and firm in the heart (qalb)." ${ }^{58}$ Hence, one can know through the faculty of the heart that God exists in a basic manner, but this knowledge will only be basic to those whose fitra is functioning properly in tandem with the heart. Therefore, given that premises (1) through (3) outline, in accordance with Ibn Taymiyya's epistemic scheme, a way in which belief in God may be acquired in the basic sense, one ought to consider the means by which this cognitive process may originate.

These basic beliefs about God arise through an apprehension or experience of God's 'signs', such that, upon these apprehensions theistic belief will be immediate and involuntary. Thus, we must here introduce Ibn Taymiyya's theory of signs (ToS). The ToS is a concept related to the Qur'anic term àya. The word aya has multiple meanings such as “"sign', 'token', 'miracle', or 'verse of the Qur'an". ${ }^{59}$ An ayya is said to be a "sign' in the sense of a token of God's power and will." For Ibn Taymiyya, an àya has a certain function in being a 'proof' of God. Von Kügelgen elaborates on this thesis and states that this is what Ibn Taymiyya refers to as "'God's method of proof through signs' (istidlälubu ta 'äläbil-äyät), and [he] considers it an immediate - that is a fițriknowledge - insofar as the signs indicate the existence of one Creator". ${ }^{11}$ As von Kügelgen understands it, the notion of signs (āyatt) as 'proof is intrinsically linked to the fitra. Ibn Taymiyya explains this connection between the fitra and signs elsewhere, where he writes that, "the proper way to prove the existence of God is to point to signs ( $\bar{a} y \bar{a} t)$. This is the way of the Qur'an, and this is what is inherent in our fit $\mathrm{ra}$ ”. ${ }^{2}$ How then does a 'sign' function as a proof? The Qur'an makes mention of 'signs' in many passages. In fact, the Qur'an itself is made up of signs: each verse of the Qur'an is referred to as an àya. Consider some Qur'anic instances:

The night, the day, the sun, the moon, are only a few of His signs. ${ }^{63}$

There are truly signs ... in the alternation of night and day, for those with understanding. ${ }^{64}$

There are signs in the heavens and earth for those who believe. ${ }^{65}$

In the Qur'anic passages above, one finds mention of circumstances, events or phenomena that act as 'signs' of God such that upon their apprehension, the truth of God's existence, to which they point, will become manifest. Ibn Taymiyya explains that God sends prophets with these signs in the form of miracles or revelation in order to awaken the fitra within. He writes:

No Prophet has ever addressed his people and asked that they should first of all know their Creator, that they should look into various arguments and infer from them His existence. Everyone is born with the fitra, only that something happens afterwards which 
casts a veil over it. Hence, when one is reminded, one recalls what was there in one's original nature. $^{66}$

In other words, the prophets are sent to remind people and to reawaken the intimate knowledge of God within all human beings: "The prophets only come with that which reminds the fitra of truths already known to it". ${ }^{67}$ Therefore, 'signs' do not function as a proof without their intrinsic connection to fitra. When the fitra is sound, it apprehends these signs, producing basic beliefs about God via the intuition of the heart. These 'signs' are vast in number and can produce an overwhelming intuition that God's presence is with us, or that He is the world's Maker. This may occur upon observing the splendor and glory of the night sky, in pondering the vastness of the universe, or even upon observing the mercy of a mother toward her child. Through encountering these 'signs', one can come to know God in an immediate and basicway. Consequently, the ToS elucidates a more specific element of the cognitive process: it points toward the precise way in which basic belief about God can arise in the heart through the natural workings of the fitra. Then, in so far as premise (1) through (4) are more probably true than false, it seems to follow from premise (5) that through the epistemic role of the fitra, in connection with the heart and upon one's acquaintance with God's 'signs', basic belief in His existence can arise in an immediate manner without deliberation.

In his article "Ibn Taymiyya on the existence of God" (1991), Wael Hallaq writing on the relationship between the fittra and äyät, suggests that one approach to understanding this relationship is in terms of the fitra representing "a medium for knowing the existence of God through the necessary sense perception of signs [i.e., through man's external and internal senses]." He adds that if this interpretation is the case, then Ibn Taymiyya "seems to construct a valid argument grounded in an empiricist metaphysics" ${ }^{69}$ However, I think that this interpretation and construction of Ibn Taymiyya's thesis does not properly mark out the distinction between a syllogistic argument (qiyass) and signs (āyat) as distinct methods for acquiring true beliefs. Ibn Taymiyya writes:

The difference between sign (äya) and syllogism (qiyass) is that the sign is an indication, that is to say, the indicant that entails the very thing indicated. ${ }^{70}$

Yet, the crucial question is, how is one said to be epistemically justified in upholding the 'knowledge' one derives from encountering these 'signs' in the context of theistic belief? For surely it cannot be in the same manner in which arguments are said to be justified, i.e., solely in terms of their validity and soundness, for signs are strictly distinct from such traditional arguments according to Ibn Taymiyya. Moreover, as Plantinga states in the context of his own model, "It isn't 
that one beholds the night sky, notes that it is grand, and concludes that there must be such a person as God: an argument like that would be ridiculously weak." 71 Thus, it seems to me, the proper way to conceive of the function of signs as a method of proof, and one that is epistemically justified, is not in terms of propositional evidence. Instead, it ought to be viewed in the context of the 'proper function' of the fitra when encountering God's signs, where one can be justified upon their apprehension of these signs in proper functionalist terms.

Interestingly, however, Baldwin dismisses a 'theory of signs' in his paper. He attempts to formulate an account of how a 'theory of signs' may work in the following way: (1) he compares the notion of signs to 'everyday' signs, such as "street signs, addresses in a phone book, or words in a biology text or on the back of a cereal box"; (2) he suggests that these 'signs' can be analogous to 'signs of God' in the universe, such as its delicate order or design, which testifies to a designer behind it. In the case of the 'every day signs', we apprehend their meanings immediately, without deliberation. So the same can be for the signs of God: we can have knowledge of both these sets of signs in an immediate and basic way. ${ }^{72}$ However, Baldwin rejects the plausibility of this theory in the end because (a) "acquiring proper knowledge of God is not relevantly similar to reading words on the back of a cereal box", and (b) on this account of the theory of signs, he says that it would still be "sensible to doubt whether one has had a legitimate experience of God". 73

It seems that Baldwin's account of the ToS fails to capture what is meant by an ajya in terms of its epistemic function. Gaining immediate knowledge from an aya is not merely the apprehension of what it is; it is an indication of something beyond it. On the Taymiyyan model as I have outlined it, a sign of the divine - such as my own existence, grasped by the proper functioning of the heart and fitra-produces the basic belief that there must be a maker of me and of the world as a whole. In the case of words in a biology text book functioning as a 'sign', all I am said to be doing in this case is apprehending in a basic manner the meanings of the words in the text; but this is only analogous to my immediate apprehension of the meaning of the words of the Qur'an. The àyat of the Qur'an do not simply act as signs in this trivial sense; rather, they are signs of their Author, signs of something beyond what they simply state at face value. As Ibn Taymiyya explains, "The sign (ajya) indicates the object itself of which it is the sign. Every created being is a sign and a proof of the Creator Himself." 74 Second, regarding point (b) above, this seems only to make sense based on the presuppositions of a certain type of design plan. For according to the Taymiyyan model, God is said to have designed the faculties of the human being - in particular the heart and fitra - whereby a proper functioning of these faculties will produce true, natural knowledge of Him which one knows in a basic way; and, according to this 'design plan', one's experience here can be free of doubt. Therefore, it is entirely possible, based on the ToS and the 
design plan outlined in the Taymiyyan model, that one can be sure that one's experience is legitimate.

Therefore, in so far as the theory of signs I have offered avoids Baldwin's objections the Taymiyyan model seems to have demonstrated a way in which theistic belief can arise in a basic manner. Yet, given that this model seeks to target Islamic belief more specifically, it is imperative that we now consider how this extension to include Islamic belief may occur.

\section{Extending the Standard Taymiyyan Model}

An extension of the Taymiyyan model is an attempt to account for how the central tenets of Islamic belief, i.e., the fundamental doctrines of the Qur'an, can arise within a subject in the basic way. This can be made plausible by further reference to the ToS and a more specific reference to the Qur'an. The Qur'anic verses are referred to as 'signs'. Fatani explains that "the verses are called signs [äyat] because they are taken to be indications of the truth of the book ... [hence] the word aya points simultaneously to both God and the verses of the Qur'an within which his signs are conveyed". ${ }^{75}$ The primary disciple of Ibn Taymiyya, Ibn Qayyim al-Jawziyya (d. 1350), similarly explained that "in the Qur'an, God invites His servants to know Him through two ways: one by contemplating the creation, the other by pondering over the Qur'an and contemplating its meanings. The first are His signs that are seen and witnessed; the second, His signs that are read and understood. ${ }^{, 76}$ Therefore, just as the Qur'an points us toward numerous signs in creation, the book itself contains signs of a more intimate nature. Through apprehending these signs of God that are "read and understood", basic belief in the truth of these 'signs' will mean that the subject can have an immediate apprehension of the Author behind them, and the reality of His message for humanity. Therefore, basic belief in the revealed nature of the Qur'an can be arrived at in this basic way, similar to the manner in which general theistic belief can be produced, through the proper function of the heart in conjunction with fit ra.

Thus, we may bring the standard model together with these additional points of extension to complete the full Taymiyyan model:

(1) $-(5)$

(6) Just as God has made available an immediate apprehension of His existence by reference to His 'signs' in the external world, so too has He permitted more intimate knowledge of Him through 'signs' in the form of His revelation.

(7) Through an apprehension of these 'signs' that are "read and understood", human beings are able to understand the truth of God's revelation in a basic manner and, consequently, the truth of His religion and the purpose He has in store for them. 
(8) Human beings are able to know that these 'signs' are God's words written as a message to mankind and that Islam is the religion of God to be followed by all. This immediate belief arises through the natural workings of the fitra in conjunction with the heart in an immediate fashion upon apprehension of these 'signs (that is, the verses of the Qur'an).

(9) Therefore, full-fledged Islamic belief can be grasped in an immediate and basic way according to this model, in accordance with the design plan upon which God has created human beings.

\section{Meeting Plantingan Criteria}

Having outlined the Taymiyyan model in full, one must now consider more closely whether it is in fact compatible with the epistemic requirements of Plantinga's A/C model. We can compare the two models with reference to the three distinct elements that Baldwin mentioned: the dependency, immediacy and design theses. Consider the three theses restated:

(1) The Dependency Thesis: Human beings are epistemologically and ontologically dependent on God.

(2) The Design Thesis: Human beings have been created in accordance with a design plan that aims to produce true beliefs in them about God.

(3) The Immediacy Thesis: God has endowed human beings with certain faculties such that they are able to know Him in an immediate way.

On the condition of the dependency thesis like in Baldwin's model, it is clear that the Taymiyyan model upholds this condition, given that it asserts the primacy of a Being upon whom man is dependent for his existence and henceforth his ability to know. God is the Creator of all things (khäliq kulli shay'), who "runs everything from the heavens to the earth," 77 and as Ibn Taymiyya remarks, "whatever is in the heavens or on the earth, of movement or stillness, only occurs by the will of God" ${ }^{78}$ This means, crucially, that one's knowledge resulting from the proper function of one's faculties is itself dependent upon God's will and permission, and thus man is said to be both ontologically and epistemologically dependent upon Him.

The second condition of compatibility is based on the idea that it is God who created human beings and their faculties in accordance with a particular design plan that successfully aims at producing true beliefs. Central to this thesis is a concurrence with Plantingan proper functionalism. The Taymiyyan model seems to properly concur with the Plantingan structure of a design plan according to which God has designed our faculties in order to acquire knowledge of Him. In the Qur'an, as Ibn Taymiyya references, we are told that God "gave you [mankind] hearing, sight and hearts that you might be thankful.." ${ }^{, 79}$ God gave man faculties and designed them for a wise purpose 
in order that man may know and thank Him. God also "perfected everything which He created." 80 He designed and perfected man's faculties such that they successfully aim at the acquisition of true beliefs. Just as in the Plantingan case, it follows that as long as the conditions of proper functionalism are met, namely, that one's belief is produced by cognitive faculties that are functioning properly, successfully aimed at truth, and in conjunction with epistemic environments that allow this to be brought about, then one's basic belief in Islam can be warranted in the same way that Plantingan suggests for the A/C model. According to the Taymiyyan model, upon the proper function of the heart in conjunction with the fit ra, both of which have been designed to successfully acquire true beliefs about God when placed in suitable environments for this to occur, they will produce basic belief in Islam which can be said to be warranted in a properly basic way. As outlined above, it is specifically upon contact with the 'signs of God' that basic belief in Him, and subsequently His religion, can be warranted in accordance with Plantinga's account of proper functionalism.

The Taymiyyan model is also compatible with Plantinga's immediacy thesis. It demonstrates how beliefin God can be warrantedin a properlybasicway. To reiterate, Plantinga says that something is properly basic in the following sense: ' $p$ is properly basic for $S$ in this sense if and only if $S$ accepts $p$ in the basic way, and furthermore $p$ has warrant for $S$, accepted in that way.' According to the Taymiyyan model, theistic, and specifically Islamic, belief can also be properly basic in this manner. Theistic/Islamic belief $p$ can come to person $S$ in an immediate or basic way through the proper workings of the fitra upon the heart, via one's apprehension of God's signs. Belief in God and, subsequently, Islamic doctrine comes to one in this way immediately. Second, theistic/Islamic belief $p$ seems to have warrant for $S$ accepted in this way, as per the account of the model along the lines of proper functionalism: one's belief in theism/Islam is produced by cognitive faculties that are functioning properly, successfully aimed at truth, and in conjunction with epistemic environments that allow this to be brought about. It follows that $p$ has warrant for $S$ accepted in the basicway: hence, $p$ is a properly basic belief. Therefore, belief in God and, by extension, Islam can be held by a person in the immediate or basic manner without additional requirements or recourse to argument, deliberation or demonstration.

Finally, the Taymiyyan model mirrors the A/C model in terms of its explicitor strong externalism. Contrary to Baldwin's model, which appears to strike a balance between elements of internalism and externalism, subsequently losing the spirit of both and drifting away from the essence of Plantinga's RE, the Taymiyyan fitra-based model of signs is wholly externalist in nature. It holds that external, rather than internal factors are responsible for warrant and justification. A subject does not have to have access to the reasons or evidence that relates to his theistic or Islamic belief 
being warranted. Nor does he have to engage in some form of conscious and active awareness at the second-order level by which he can know or demonstrate the truth of his first-order beliefs about God and Islam. Rather, he is justified and warranted in the fullest sense by the mere proper functioning of his faculties, in concurrence with the conditions of proper functionalism. These conditions are upheld together in reference to the design, immediacy and dependency theses. Therefore, the Taymiyyan fitra-based model of signs seems to be whollycompatible with Plantingan $\mathrm{RE}$ and seems to be a genuine extension of the A/C model in an Islamic milieu.

\section{References}

al-Bukhārī, Muhammad. Șậḥ al-Bukhārì. Beirut: Dār Ṭawq al-Najāt, 2001.

Alston, William. "Justification externalism - pro and con." In Internalism and externalism in epistemology; the Routledge Encyclopedia of Philosophy. Taylor and Francis, 1998. Retrieved 27 Apr. 2019:https://www.rep.routledge.com/articles/thematic/internalism-and-externalism-inepistemology/v-1/sections/justification-externalism-pro-and-con. Accessed 11 May 2019.

Anjum, Ovamir. Politics, Law and Community in Islamic Thought: The Taymiyyan Movement. New York: Cambridge University Press, 2012.

Baldwin, Erik. "On the Prospects of an Islamic Externalist Account of Warrant." In Classical Issues in Islamic Philosophy and Theology Today, edited by A-T. Tymieniecka and Nazif. Muhtaroglu, 19-41. Dordrecht: Springer, 2010.

Baldwin, Erik, McNabb, Tyler. Plantingan Religious Epistemology and World Religions: Prospects and Problems. Maryland: Lexington Books, 2018.

Bergmann, Michael. Justification without Awareness: A Defense of Epistemic Externalism. New York: Oxford University Press, 2006.

Black, Deborah. "Certitude, justification, and the principles of knowledge in Avicenna's epistemology." In Interpreting Avicenna: Critical Essays, edited by Peter Adamson, 120-142. Cambridge: Cambridge University Press, 2013.

BonJour, Laurence. "Externalist Theories of Empirical Knowledge.” In Epistemology: An Anthology edited by Ernest Sosa, Jaegwon Kim, Jeremy Fantl, and Matthew McGrath, 363-378. Oxford: Blackwell Publishing Ltd, 2008.

BonJour, Laurence, and Sosa, Ernest. Epistemic Justification: Internalism vs. Externalism, Foundations vs. Virtues. Oxford: Blackwell Publishing Ltd, 2003.

Boyce, Kenneth, and Plantinga, Alvin. "Proper Functionalism." In The Continuum Companion to Epistemology edited by Andrew Cullison, 124-140. New York: Continuum International Publishing Group, 2012.

Brown, Jessica. "Externalism in Mind and Epistemology." In Internalism and Externalism in Semantics and Epistemology, Sanford .C. Goldberg, 13-34. New York: Oxford University Press, 2007.

Chisholm, Roderick M. Theory of Knowledge. New-Jersey: Prentice-Hall International, Inc, 1989. 
Dougherty, Trent, and Tweedt, Chris. "Religious Epistemology." Philosophy Compass 10, no. 8 (July 2015): 547-559.

Fatani, Afnan. H. “AYA.” In The Quran: an Encyclopedia edited by Oliver Leaman, 85-103. New York: Routledge, 2006.

Hallaq, Wael. Ibn Taymiyya against the Greek Logicians. New York: Oxford University Press, 1993.

Hallaq, Wael. "Ibn Taymiyya on the existence of God." Acta Orientalia 52, (1991): 49-69.

Hoover, Jon. Ibn Taymiyya's Theodicy of Perpetual Optimism. Leiden: Brill, 2007.

Ibn Qayyim al-Jawziyya. al-Fawä id. Riyadh: Maktabat al-Rushd, 2001.

Ibn Taymiyya, Taqī al-Dīn. al-'Aqīda al-Wāșițiyya. Riyadh: Aḍwā' al-Salaf, 1999.

Ibn Taymiyya, Taqī al-Dīn. Amrāẹ al-qulūb wa-shifäu’uhā. Cairo: al-Maṭba'a al-Salafiyya, 2018.

Ibn Taymiyya, Taqī al-Dīn. Dar' ta 'áruḍ al-'aql wa-l-naql. Riyadh: Jāmi'at al-Imām Muḥammad b. Sa'ūd al-Islāmiyya, 1991.

Ibn Taymiyya, Taqī al-Dīn. Majmū' Fatāwā Shaykh al-Islām Ahmad b. Taymìya. Mujamma‘ al-Malik Fahd, 1995.

Lane, William. Arabic-English Lexicon. London: Williams and Norgate, 1863.

Mohamed, Yasien. Fitrab: The Islamic Concept of Human Nature. London: Ta-Ha Publishers Ltd, 1996.

Moon, Andrew. "Recent Work in Reformed Epistemology." Philosophy Compass 11, no. 12 (December 2016): 879-891.

Özervarli, Mehmet. Sait. "Divine Wisdom, Human Agency and the fitra in Ibn Taymiyya's Islamic Thought." In Islamic Theology, Philosophy and Law: Debating Ibn Taymiyya and Ibn Qayyim al-Jawriyna, Alina Kokoschka, Birgit. Krawietz, and Georges Tamer, 37-60. De Gruyter: Berlin/Boston, 2013.

Plantinga, Alvin. "Reformed Epistemology." In A Companion to Philosophy of Religion, edited by Charles Taliaferro, Paul Draper, and Philip L. Quinn, 674-680. Oxford: Blackwell Publishing Ltd, 2010.

Plantinga, Alvin. Warranted Christian Belief. New York: Oxford University Press, 2000.

Plantinga, Alvin. Warrant: The Current Debate. New York: Oxford University Press, 1993.

Sudduth, Michael. The Reformed Objection to Natural Theology. New York: Routledge, 2016.

The Qur'an (Oxford World Classics), trans. M. A. S. Abdel Haleem. Oxford: Oxford University Press, 2008.

Vasalou, Sophia. Ibn Taymiyya's Theological Ethics. New York: Oxford University Press, 2016.

von Kügelgen, Anke. "The Poison of Philosophy: Ibn Taymiyya's Struggle For and Against Reason. In Islamic Theology, Philosophy and Law: DebatingIbn Taymiyya and Ibn Qayyim al-Jawriyya, Alina Kokoschka, Birgit. Krawietz, and Georges Tamer, 253-328. De Gruyter: Berlin/Boston, 2013. 
1 Andrew Moon, "Recent Work in Reformed Epistemology," Philosophy Compass 11, no. 12 (December 2016): 879 .

2 Laurence Bonjour and Ernest Sosa, Epistemic Justification: Internalism vs. Externalism, Foundations vs. Virtues (Oxford: Blackwell Publishing, 2003) 24.

${ }^{3}$ Laurence BonJour, "Externalist Theories of Empirical Knowledge," in Epistemology: An Anthology, ed. Ernest Sosa, Jaegwon Kim, Jeremy Fantl, and Matthew McGrath (Oxford: Blackwell Publishing, 2008), 363-78.

4 Bonjour and Sosa, Epistemic Justification: Internalism vs. Externalism, Foundations vs. Virtues, 1.

5 Alvin Plantinga, "Warrant: The Current Debate," (New York: Oxford University Press, 1993) 3.

6 See (Boyce and Plantinga 2012, 124-140) for a concise and comprehensive account of the theory.

7 The points (1-4) are a summary of Plantinga's account provided in Warranted Christian Belief. See (Plantinga 2000, pp. 130-33).

8 As Plantinga notes, this is not to suggest a divinely ordained plan, it could be thought to mean the 'design-plan' as a result of a blind evolutionary process for instance.

${ }^{9}$ Ibid. 144.

10 Baldwin and McNabb together co-authored; Plantingan Religious Epistemology and World Religions: Prospects and Problems (2018). There they put forward this model, but it was originally outlined by Baldwin (2010).

11 Ibid. 27.

12 See (Baldwin 2010, p. 27).

13 Baldwin, "On the Prospects of an Islamic Externalist Account of Warrant," 27.

14 Ibid. 28-29.

15 Ibid. 29

16 Ibid. 29-30.

17 Ibid. 30.

18 Deborah Black, "Certitude, justification, and the principles of knowledge in Avicenna's epistemology," in Peter Adamson, ed. Interpreting Avicenna: Critical Essays (Cambridge: Cambridge University Press, 2013), 140-41.

19 BonJour and Sosa, Epistemic Justification: Internalism vs. Externalism, Foundations vs. Virtues, 24.

20 Baldwin, "On the Prospects of an Islamic Externalist Account of Warrant," 22.

21 Erik Baldwin and Tyler McNabb, Plantingan Religious Epistemology and World Religions: Prospects and Problems (Maryland: Lexington Books, 2018), 227.

22 Trent Dougherty and Chris Tweedt, "Religious Epistemology," Philosophy Compass 10, no. 8 (July 2015): 548.

${ }^{23}$ Roderick Chisholm, Theory of Knowledge (New-Jersey: Prentice-Hall International, Inc, 1989), 76.

24 William Alston, "Justification externalism - pro and con. In Internalism and externalism in epistemology," in The Routledge Encyclopedia of Philosophy, (Taylor and Francis, 1998). Retrieved 27 Apr. 2019:https://www.rep.routledge.com/articles/thematic/internalism-and-externalism-inepistemology/v-1/sections/justification-externalism-pro-and-con. Accessed 11 June 2019.

${ }^{25}$ Jessica Brown, "Externalism in Mind and Epistemology," in Sanford C. Goldberg, ed. Internalism and Externalism in Semantics and Epistemology, (New York: Oxford University Press, 2007), 13-14.

${ }^{26}$ Michael Bergmann, Justification without Awareness: A Defense of Epistemic Externalism (New York: Oxford University Press, 2006), 13.

27 Ibid. 50.

28 Ibid. vii.

${ }^{29}$ Ibid. 9. 
30 Baldwin, "On the Prospects of an Islamic Externalist Account of Warrant," 25-26.

31 Ibid. 26.

32 Baldwin and McNabb, Plantingan Religious Epistemology and World Religions: Prospects and Problems, 217.

33 Alvin Plantinga, Warranted Christian Belief (New York: Oxford University Press, 2000), 148-49.

34 Baldwin, "On the Prospects of an Islamic Externalist Account of Warrant," 31.

35 Ibid. 35.

36 Michael Sudduth, The Reformed Objection to Natural Theology (New York: Routledge, 2016), 85.

37 Mehmet Sait Özervarli, "Divine Wisdom, Human Agency and the fitra in Ibn Taymiyya's Islamic Thought," in Alina Kokoschka, Birgit Krawietz and Georges Tamer, ed. Islamic Theology, Pbilosophy and Law: Debating Ibn Taymiyya and Ibn Qayyim al-Jawriyya, (De Gruyter: Berlin/Boston, 2013), 54.

${ }^{38}$ For example, Ibn Taymiyya does not necessarily reject the use of arguments for God's existence as a means to obtain knowledge of Him in certain cases. See (Ibn Taymiyya, Dar' ta'ärud al-aql wa-l-naql, vol. 7, 219).

39 The word here used for 'minds' is afida plural of fu'äd. Lane explains that fu'äd. literally means heart but also refers to; "mind, or intellect: and this, it is said to be the meaning of the phrase [in the Qur'an]." (Lane 1863, pp. 2323-2324).

40 The Qur'an (Oxford: Oxford University Press, 2008), 16:78.

41 The Qur'an, 76:1-3.

${ }^{42}$ Ovamir Anjum, Politics, Law and Community in Islamic Thought: The Taymiyyan Movement (New York: Cambridge University Press, 2012), 215.

43 Yasien Mohamed, Fitrab: The Islamic Concept of Human Nature (London: Ta-Ha Publishers Ltd, 1996). 13-14.

${ }^{44}$ The Qur'an, 30:30.

45 Muhammad al-Bukhārī, Șạhị al-Bukehārì (Beirut: Dār Ṭawq al-Najāt, 2001), vol. 6, 114.

46 Taqī al-Dīn Aḥmad Ibn Taymiyya, Majmū‘ Fatāwā Shaykh al-Islām Aḥmad b. Taymiyya (Mujamma‘ al-Malik Fahd, 1995), vol. 4, 245-46.

47 Ibid. 246.

48 Jon Hoover, Ibn Taymiyya's Theodicy of Perpetual Optimism (Leiden: Brill, 2007), 42.

49 Sophia Vasalou, Ibn Taymiyya's Theological Ethics (New York: Oxford University Press, 2016), 80-81.

${ }^{50}$ Taqī al-Dīn Ahmad Ibn Taymiyya, Dar'ta'ärud al-aql wa-l-naql (Riyadh: Jāmi'at al-Imām Muhammad b. Sa'ūī al-Islāmiyya, 1991), vol8, 458-49.

51 See for example: (Ibn Taymiyya 1995, vol. 9, p. 309-310).

52 Taqī al-Dīn Ahmad Ibn Taymiyya, Dar' ta'ärud al-'aql wa-l-naql, vol. 5, 62.

53 Ibid. 62.

54 Taqī al-Dīn Aḥmad Ibn Taymiyya, Majmū̌ Fatāwā Shaykh al-Isläm Aḥmad b. Taymiyya, vol. 9, 313.

55 Ibid. 313.

56 Taqī al-Dīn Aḥmad Ibn Taymiyya, Amrạ̈ al-qulüb wa-shifäunhā. (Cairo: al-Maṭaca al-Salafiyya, 2018), 26.

57 Taqī al-Dīn Ahmad Ibn Taymiyya, Majmū Fatāwā Shaykh al-Islām Ahmad b. Taymìyya, vol. 6, 73

58 Taqī al-Dīn Aḥmad Ibn Taymiyya, Majmū Fatäwà Shaykh al-Isläm Ahmad b. Taymìyya, vol. 16, 461.

59 Afnan H. Fatani, "AYA," The Quran: an Encyclopedia, in Oliver Leaman, ed. (New York: Routledge, 2006), 85.

60 Ibid. 85.

${ }^{61}$ Anke Von Kügelgen "The Poison of Philosophy: Ibn Taymiyya's Struggle For and Against Reason," in Alina Kokoschka, Birgit Krawietz and Georges Tamer, ed. Islamic Theology, Pbilosophy and Law: Debating Ibn Taymiyya and Ibn Qayyim al-Jawriyya, (De Gruyter: Berlin/Boston, 2013), 323. 
62 Taqī al-Dīn Aḥmad Ibn Taymiyya, Majmū‘ Fatāwà Shaykeh al-Isläm Ahmad b. Taymìyya, vol. 1, 48.

${ }^{63}$ The Qur'an, 41:37

64 The Qur'an, 3:190.

65 The Qur'an, 45:3.

66 Taqī al-Dīn Aḥmad Ibn Taymiyya, Majmū‘ Fatäwā Shaykh al-Isläm Ahmad b. Taymìyya vol. 16, 338.

67 Ibid. 338.

68 Wael Hallaq, "Ibn Taymiyya on the existence of God", Acta Orientalia 52 (1991): 66.

${ }^{69}$ Ibid. 66.

70 Wael Hallaq, Ibn Taymiyya against the Greek Logicians (New York: Oxford University Press, 1993), 71.

71 Alvin Plantinga, Warranted Christian Belief, 146.

72 Baldwin, "On the Prospects of an Islamic Externalist Account of Warrant," 32.

73 Ibid. 33.

${ }^{74}$ Taqī al-Dīn Aḥmad Ibn Taymiyya, Majmū‘ Fatāwà Shaykeh al-Isläm Ahmad b. Taymìyya, vol. 1, 48.

75 Fatani, “AYA," 85.

76 Ibn Qayyim al-Jaw ziyya, al-Fawä id (Riyadh: Maktabat al-Rushd, 2001), 42-43.

77 The Qur'an, 32:5.

78 Taqī al-Dīn Aḥmad Ibn Taymiyya, al-'Aqüda al-Wäșițiyya (Riyadh: Aḍ̂ā' al-Salaf, 1999), 107.

79 The Qur'an, 16:78.

80 The Qur'an, 32:7. 